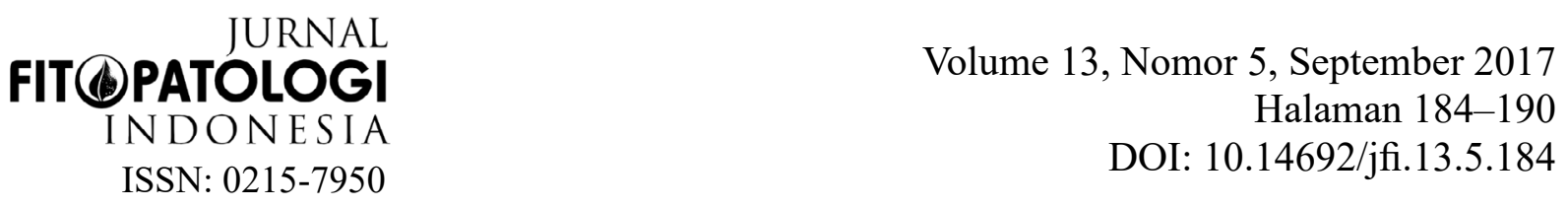

\title{
Penyakit Layu Bakteri Stewart pada Jagung di Bali
}

\author{
Stewart's Wilt Disease of Maize in Bali \\ I Gede Rai Maya Temaja*, G.N. Alit Susanta Wirya, Ni Made Puspawati, \\ Khairun Nisak Syahdu \\ Universitas Udayana, Denpasar 80225
}

\begin{abstract}
ABSTRAK
Penyakit layu stewart merupakan penyakit serius pada tanaman jagung manis (Zea mays). Gejala khas penyakit ini ialah garis berwarna hijau pucat sampai kekuningan yang sejajar dengan tulang daun. Gejala seperti ini ditemukan pada daun jagung manis di daerah Denpasar, Tabanan, Gianyar dan Karangasem pada tahun 2015. Deteksi patogen dengan metode polymerase chain reaction dilakukan menggunakan DNA total yang diisolasi dari daun tanaman bergejala dan pasangan primer CPSL1/ CPSR2c. Amplikon dengan ukuran $\sim 1100 \mathrm{pb}$ berhasil diperoleh dari sampel asal Denpasar. Analisis sikuen nukleotida memastikan bahwa gejala penyakit layu stewart tersebut disebabkan oleh bakteri Pantoea stewartii subsp. stewartii. Hasil analisis sikuen menunjukkan bahwa P. stewartii subsp. stewartii isolat Bali memiliki tingkat homologi yang tinggi (98.97-99.08\%) dan berada dalam satu clade dengan isolat asal Kanada, Amerika Serikat, dan Jepang. Ini merupakan laporan pertama mengenai P. stewartii subsp. stewartii yang menginfeksi tanaman jagung di Provinsi Bali.
\end{abstract}

Kata kunci: analisis sikuen, nukleotida, Pantoea, Zea mays

\begin{abstract}
Stewart's wilt is a serious disease of sweet corn (Zea mays). The typical symptoms of the disease are pale-green to yellow linear streaks parallel to the veins. The symptoms were observed on sweet corn in Denpasar, Tabanan, Gianyar, and Karangasem areas during a survey in 2015. Pathogen detection based on a polymerase chain reaction was carried out using total DNA obtained from symptomatic leaf samples and the pairs of primers, CPSL1/CPSR2c. The expected sized ( $1100 \mathrm{bp})$ amplicon was detected in samples from Denpasar. Sequence analysis confirmed that Stewart's wilt disease symptoms are caused by Pantoea stewartii subsp. stewartii. Nucleotide sequence and phylogenetic analysis showed that $P$. stewartii subsp. stewartii from Bali has high homology (98.97-99.08 \%) and placed in the same clade with isolates from Canada, USA and Japan. This is the first report of P. stewarti subsp. stewartii on corn in Bali.
\end{abstract}

Key words: nucleotide, sequence analysis, Pantoea, Zea mays

*Alamat penulis korespondensi: Fakultas Pertanian, Universitas Udayana, Jalan PB Sudirman, Denpasar, Bali 80225.

Tel: 0361-255346, Faks: 0361-255346; surel: raitemaja@unud.ac.id 


\section{PENDAHULUAN}

Jagung (Zea mays) adalah salah satu bahan pangan pokok di Indonesia dan juga merupakan komponen utama pangan dan pakan ternak dan unggas. Kebutuhan jagung di Indonesia belum bisa dipenuhi dari produksi dalam negeri, sehingga masih harus dilakukan impor. Pada tahun 2013 impor jagung sebesar 3.19 juta ton, volume impor ini naik $76.94 \%$ dibandingkan dengan tahun 2012. Pada tahun 2014 volume impor jagung belum berubah dari tahun sebelumnya yaitu sebesar 3.17 juta ton (Pusat Data dan Sistem Informasi Pertanian Kementan 2015).

Tingginya impor jagung ke Indonesia, meningkatkan kemungkinan masuk dan tersebarnya OPTK A1 yang dapat terbawa melalu biji jagung, salah satunya ialah Pantoea stewartii subsp. stewartii. Bakteri tersebut merupakan penyebab penyakit layu stewart yang endemik di Amerika dan telah tersebar di beberapa negara di dunia (OEPP/EPPO 2006). Bakteri ini menyebabkan layu vaskular dan hawar pada daun (Coplin et al. 2002). Penyakit layu stewart telah menimbulkan masalah besar bagi negara produsen jagung, yaitu mengakibatkan kehilangan hasil. Pada jagung manis, kehilangan hasil berhubungan dengan infeksi sistemik, yaitu pengurangan hasil $0.8 \%$ untuk setiap insidensi penyakit $1 \%$ dari bibit tanaman terinfeksi sistemik (Freeman dan Pataky 2001).

P. stewartii subsp. stewartii pertama kali dilaporkan menginfeksi tanaman jagung di Bogor, Jawa Barat pada tahun 2014 (Rahma et al. 2014). Gejala penyakit layu stewart ditandai dengan perubahan warna daun dari hijau pucat ke kuning, disertai garis linear teratur atau tepinya bergelombang sejajar dengan tulang daun. Survei pada tahun 2015 menemukan penyakit yang menunjukkan gejalamenyerupai infeksi penyakit layu stewart pada daun jagung manis di Desa Kesiman Kertalangu, Kota Denpasar. Penyakit seperti ini belum pernah dijumpai pada tanaman jagung di Bali. Oleh karena itu, penelitian ini bertujuan mengidentifikasi penyebab gejala layu stewart pada tanaman jagung di Bali.

\section{BAHAN DAN METODE}

\section{Survei Penyakit}

Survei untuk mendapatkan status penyebaran penyakit layu stewart dilakukan di semua kabupaten dan kota di Bali. Pengamatan meliputi tanaman jagung yang menunjukkan gejala layu stewart. Pengambilan sampel di lapangan dilakukan pada tanaman yang bergejala secara acak. Sampel tanaman jagung dicabut dan dimasukkan ke dalam plastik untuk selanjutnya dideteksi patogen penyebabnya dengan metode polymerase chain reaction (PCR).

Insidensi penyakit (IP) dan keparahan penyakit (KP) diukur menggunakan rumus:

$$
\mathrm{IP}=\frac{\mathrm{n}}{\mathrm{N}} \times 100 \% \text {, dengan }
$$

$\mathrm{n}$, jumlah tanaman yang terserang; dan $\mathrm{N}$, jumlah tanaman yang diamati.

$$
\mathrm{KP}=\frac{\sum_{\mathrm{i}=0}^{i}\left(\mathrm{n}_{i} \times \mathrm{v}_{i}\right)}{\mathrm{N} \times \mathrm{V}^{*}} 100 \% \text {, dengan }
$$

$\mathrm{n}_{\mathrm{i}}$ jumlah tanaman dengan skor ke-i; $\mathrm{v}_{\mathrm{i}}$, nilai skala dari tiap kategori serangan (Tabel 1); $\mathrm{N}$, jumlah tanaman yang diamati; dan $\mathrm{V}$, skor tertinggi.

\section{Deteksi Patogen dengan PCR}

Ekstraksi DNA dan Amplifikasi Gen cps. DNA total diekstrak dari daun jagung bergejala menggunakan kit ekstraksi DNeasy Plant Mini Kit (Qiagen). Amplifikasi gen capsule

Tabel 1 Skala dan tingkat serangan Pantoea stewartii subsp. stewartii pada tanaman jagung

\begin{tabular}{cccc}
\hline Skala & $\begin{array}{c}\text { Tingkat } \\
\text { serangan } \\
(\%)\end{array}$ & $\begin{array}{c}\text { Kriteria } \\
\text { serangan }\end{array}$ & $\begin{array}{c}\text { Tingkat } \\
\text { virulensi }\end{array}$ \\
\hline 1 & $<1$ & Sehat & Tidak virulen \\
2 & 1 & Sangat ringan & Kurang virulen \\
3 & 2 & Sangat ringan & Kurang virulen \\
4 & 3 & Sangat ringan & Kurang virulen \\
5 & 4 & Sangat ringan & Kurang virulen \\
6 & $5-25$ & Ringan & Virulen \\
7 & $25-50$ & Sedang & Virulen \\
8 & $50-90$ & Berat & Sangat virulen \\
9 & $>90$ & Sangat berat & Sangat virulen \\
\hline
\end{tabular}

Sumber: Rahma et al. (2010) 
biosynthesis (cps) dilakukan dengan teknik PCR menggunakan pasangan primer CPSL1 (5'-CCTGTCAGTCTCGAACC-3'); dan CPSR2c (5'-ATCTCGAACCGGTAACC-3') dengan produk PCR $1100 \mathrm{pb}$. Primer CPSL1 dan CPSR2c yang dirancang dari sikuen daerah $c p s D$ mengode sintesis kapsul polisakarida stewartan yang spesifik untuk P. stewartii (Coplin et al. 2002). DNA diamplifikasi pada volume reaksi $25 \mu \mathrm{L}$ yang mengandung PCR Bead, $1 \mu \mathrm{L}(0.4 \mu \mathrm{M})$ primer CPSL1, $1 \mu \mathrm{L} \quad(0.4 \mu \mathrm{M})$ primer CPSR2c, $22 \mu \mathrm{L}$ nuclease free water, dan $1 \mu \mathrm{L}$ template DNA. Amplifikasi dilakukan pada Gene Amp PCR System 9700 thermocycler, dengan program: predenaturasi pada $94{ }^{\circ} \mathrm{C}$ selama 5 menit, dilanjutkan dengan 25 siklus denaturasi $94{ }^{\circ} \mathrm{C}$ selama 1 menit; aneling $54{ }^{\circ} \mathrm{C}$ selama 1 menit dan ekstensi $72{ }^{\circ} \mathrm{C}$ selama 30 detik. Siklus terakhir ditambah tahapan sintesis $72{ }^{\circ} \mathrm{C}$ selama 10 menit, kemudian siklus berakhir dengan suhu $4{ }^{\circ} \mathrm{C}$. Produk PCR dielektroforesis pada gel agarosa 1.2\% yang dijalankan pada $80 \mathrm{~V}$ selama 1 jam. Gel diwarnai dalam $2 \mu \mathrm{g} \mathrm{mL} \mathrm{m}^{-1}$ etidium bromida dalam bufer elektroforesis $(40 \mathrm{mM}$ Tris, $20 \mathrm{mM}$ natrium asetat, dan $1 \mathrm{mM}$ EDTA $\mathrm{pH}$ 7.0) dan divisualisasi pada transluminator UV (Bio-Rad Translluminator 2000).

Sikuensing dan Analisis Filogenetika. Analisis sikuen dilakukan oleh PT. Genetika Science Indonesia. Sikuen DNA selanjutnya diedit menggunakan piranti lunak ChromasPro versi 1.5. Analisis sikuen untuk mengetahui tingkat homologinya dengan sikuen yang telah didepositkan pada GenBank dilakukan dengan piranti lunak basic local alignment search tool (BLAST) melalui situs: http:// blast.ncbi.nlm.nih.gov/Blast.cgi (Thompson et al. 1997). Data sikuen nukleotida yang terpilih kemudian dianalisis kespesifikan nukleotidanya dengan program multiple alignment (ClustalW) yang terintegrasi pada program piranti lunak molecular evolutionary genetics analysis (MEGA) versi 6.0 (Tamura et al. 2013). Pohon filogenetika dikonstruksi menggunakan piranti lunak PAUP 4.0b10 dengan metode neighbor joining (NJ) berdasarkan pendekatan maximum parsimony
(MP) dan bootstrap 1000 ulangan (Brady et al. 2012). Selanjutnya, pohon filogenetika ditampilkan menggunakan piranti lunak TreeGraph 2.0 (Stover dan Muller 2010).

\section{HASIL}

Keberadaan pertanaman jagung, terutama jagung manis sangat berkaitan erat dengan munculnya gejala layu stewart yang disebabkan oleh bakteri $P$. stewartii subsp. stewartii. Pada penelitian ini gejala tanaman jagung yang terinfeksi layu stewart terdapat di Desa Kesiman Kertalangu, Kota Denpasar; Desa Kediri, Kabupaten Tabanan; Desa Blahbatuh, Kabupaten Gianyar; dan Desa Manggis, Kabupaten Karangasem. Gejala layu stewart yang menginfeksi tanaman jagung di daerah tersebut ialah adanya garis lurus berwarna hijau pucat sampai kekuningan sejajar dengan tulang daun pada daun (Gambar 1). Insidensi penyakit tertinggi $(23 \%)$ terjadi di Desa Kesiman Kertalangu, Denpasar, dan paling rendah (11\%) di Desa Manggis, Karangasem. Sedangkan keparahan penyakit tertinggi terdapat di kota Denpasar dan Kabupaten Gianyar sebesar $10 \%$ dan terendah terdapat di Kabupaten Karangasem yaitu sebesar 3\% (Tabel 2). Semua tanaman yang menunjukkan gejala merupakan varietas jagung manis.

Deteksi dengan PCR hanya berhasil mengamplifikasi fragmen DNA dari sampel asal Desa Kesiman Kertalangu, Kota Denpasar. Fragmen DNA berukuran $\sim 1100$ pb didapatkan dari amplifikasi menggunakan pasangan primer CPSL dan CPSR2c yang mengamplifikasi gen cps (Gambar 2). Fragmen DNA yang dihasilkan selanjutnya dipurifikasi dan disikuensing untuk mengidentifikasi bakteri berdasarkan kemiripan sikuen nukleotida dengan spesies bakteri yang telah teridentifikasi di GenBank. Berdasarkan hasil penjajaran sikuen, bakteri isolat Denpasar (yang selanjutnya dinamakan isolat Bali) memiliki kekerabatan yang dekat dengan $P$. stewartii subsp. stewartii DOAB 021 (EU215383.1) asal Kanada, P. stewartii subsp. stewartii DC283 (AF077292.2) asal USA, P. stewartii subsp. stewartii cpsD 


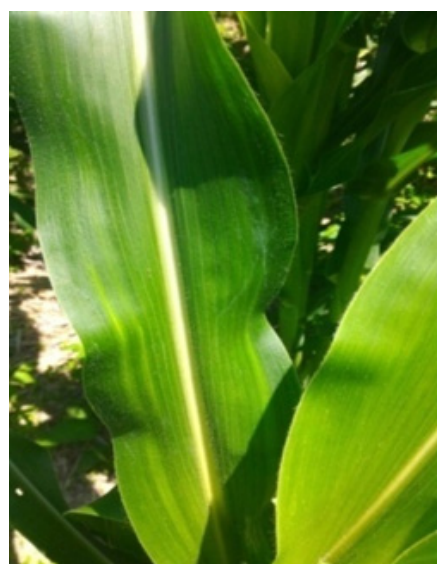

Gambar 1 Gejala layu stewart di pertanaman jagung di Desa Kesiman Kertalangu, Denpasar. Garis lurus berwarna hijau pucat sampai kekuningan yang sejajar dengan tulang daun.

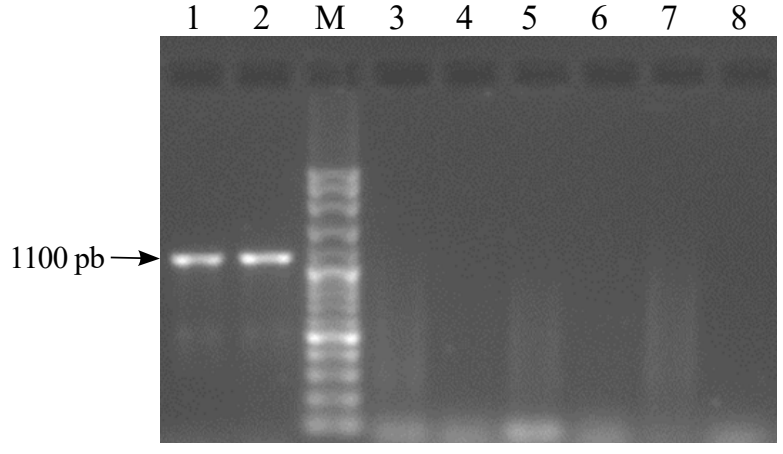

Gambar 2 Hasil amplifikasi gen cps P. stewartii subsp. stewartii menggunakan primer CPSL1 danCPSR2cSampelberasal daritanamanjagung di Provinsi Bali. 1 dan 2, Denpasar; 3 dan 4, Tabanan; 5 dan 6, Gianyar; 7 dan 8, Karangasem; M, Penanda DNA 100 pb (Fermentas).

Tabel 2 Insidensi dan keparahan penyakit layu stewart di Provinsi Bali

\begin{tabular}{lccl}
\hline Lokasi & $\begin{array}{c}\text { Insidensi penyakit } \\
(\%)\end{array}$ & $\begin{array}{c}\text { Keparahan penyakit } \\
(\%)\end{array}$ & Gejala penyakit \\
\hline Denpasar & 23 & 10 & Garis kuning membujur sejajar tulang daun \\
Tabanan & 16 & 5 & Garis kuning membujur sejajar tulang daun \\
Gianyar & 21 & 10 & Garis kuning tak beraturan sejajar tulang daun \\
Karangasem & 11 & 3 & Bercak kuning pada daun dan layu \\
\hline
\end{tabular}

(AB894429.1) asal Jepang, dan P. stewartii subsp. stewartii DOAB 022 (EU215384.1) asal Kanada (Tabel 3). Hasil analisis pohon filogenetika menggunakan metode NJ dengan 1000 kali ulangan bootstrap dan pendekatan MP menunjukkan bahwa isolat Bali ialah $P$. stewartii subsp. stewartii karena berada pada satu kelompok dengan sikuen-sikuen bakteri P. stewartii subsp. stewartii dengan dukungan $100 \%$ bootstrap support (Gambar 3).

\section{PEMBAHASAN}

Gejala penyakit layu stewart ditemukan pada tanaman jagung di Bali. Gejala layu stewart yang terdapat pada pertanaman jagung ini sesuai dengan yang diungkapkan oleh Rahma et al. (2010). Keparahan penyakit menunjukkan bahwa tingkat infeksi penyakit di lapangan tergolong ringan; belum ditemukan adanya vektor kumbang Chaetocnema pulicaria di lapangan.

Amplifikasi berhasil mendapatkan fragmen berukuran $\sim 1100 \mathrm{pb}$ hanya dari sampel daun asal Denpasar, sesuai dengan target yang diharapkan. Sampel dari daerah lain tidak teramplifikasi dikarenakan sampel tersebut tidak terinfeksi bakteri $P$. stewartii subsp. stewartii. Hal ini sesuai dengan hasil uji morfologi koloni bakteri yaitu hanya sampel asal Denpasar yang dapat dikulturkan. Diagnosis menggunakan primer spesifik cukup baik digunakan untuk $P$. stewartii subsp. stewartii apalagi bila dikombinasikan dengan analisis matrix-assisted laser desorption ionization-time of flight mass spectrometry (MALDI-TOF MS) (Wensing et al.2010).

Kedekatan jarak genetika antara isolat $P$. stewartii subsp. stewartii isolat Bali dan isolat P. stewartii subsp. stewartii dari Kanada, USA, dan Jepang dimungkinkan karena adanya lalu lintas komoditas pertanian antarnegara dan antararea sehingga bakteri tersebut dapat terbawa melalui benih yang masuk ke wilayah Provinsi Bali. Penyakit layu stewart yang disebabkan oleh bakteri $P$. stewartii subsp. stewartii muncul pertama kali di Indonesia pada tahun 2010 (Rahma et al. 2010). Hasil 


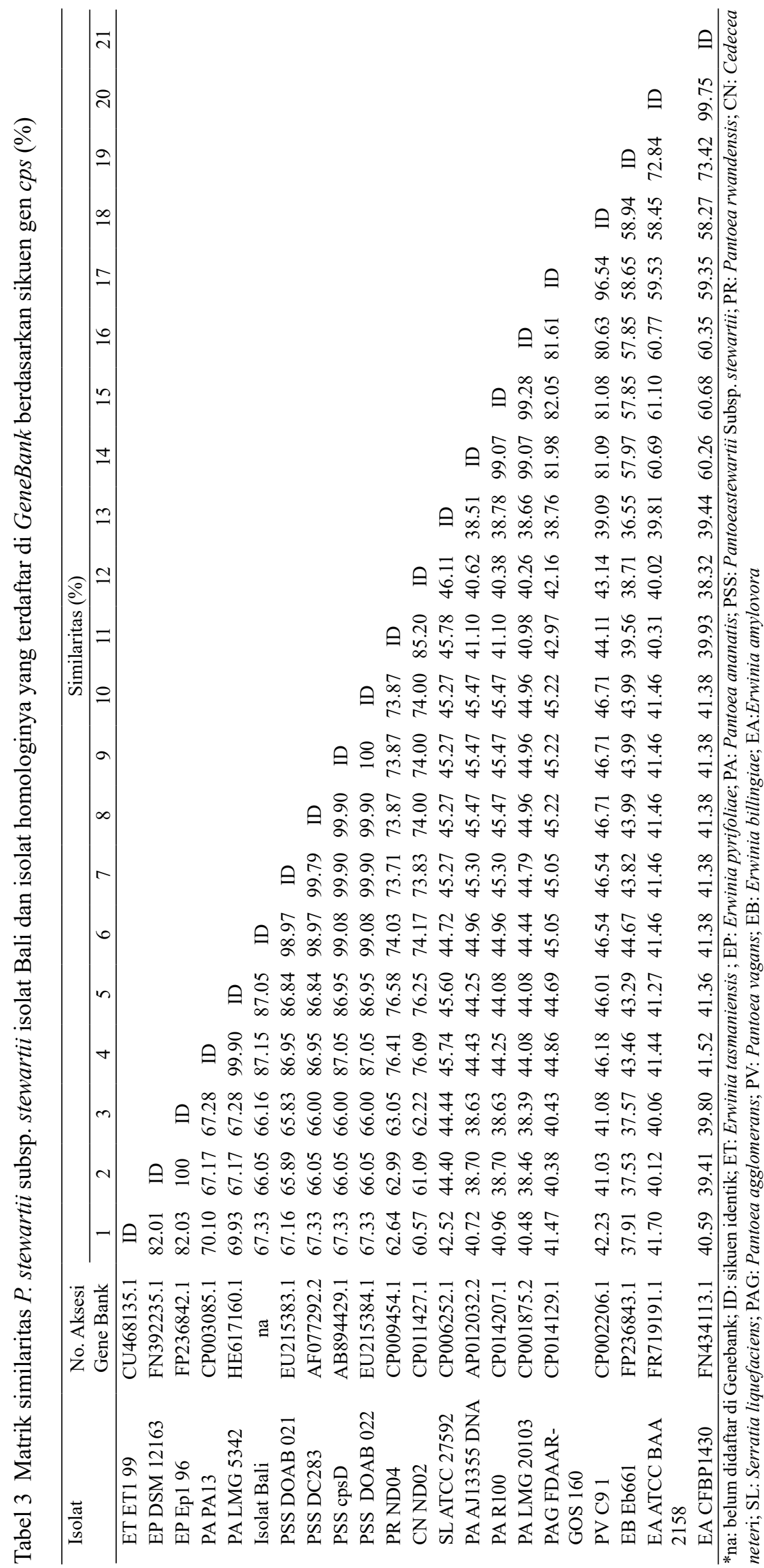




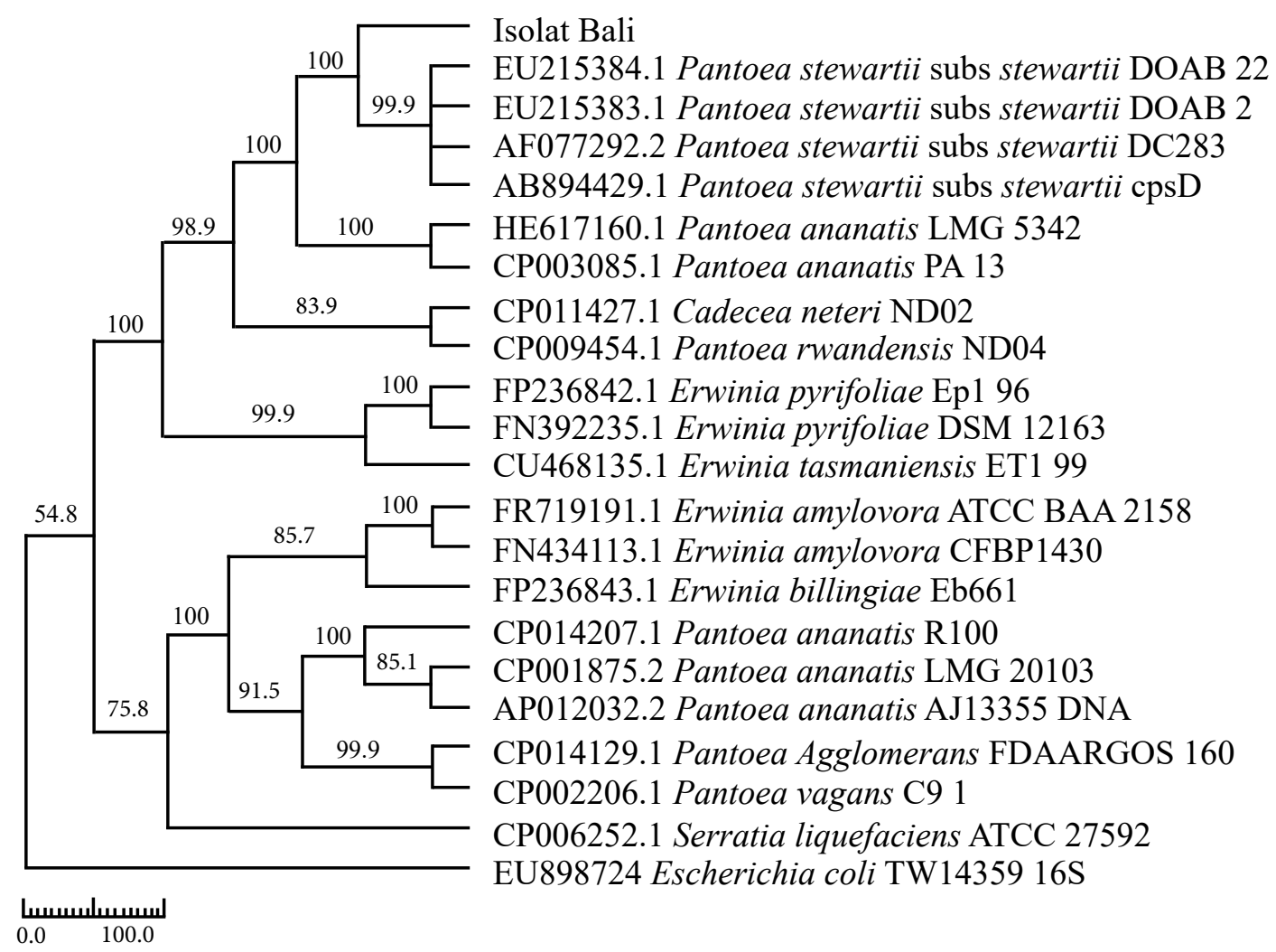

Gambar 3 Filogenetika kekerabatan P. stewartii subsp. stewartii isolat Bali terhadap galurgalur homologinya yang terdaftar di GenBank berdasarkan gen cps. Hasil analisis menggunakan metode neighbor joining dengan menggunakan 1000 kali ulangan bootstrap dan pendekatan maximum parsimony. Isolat Bali adalah $P$. stewartii subsp. stewartii dengan dukungan $100 \%$ bootstrap support.

diagnosis $P$. stewartii subsp. stewartii di Provinsi Bali menunjukkan penyebaran yang lebih luas di Indonesia, padahal sesuai dengan Peraturan Menteri Pertanian No.51 tahun 2015 P. stewartii subsp. stewartii merupakan organisme pengganggu tumbuhan karantina (OPTK) golongan A1.

Berdasarkan hasil identifikasi molekuler dapat disimpulkan bahwa isolat bakteri yang berasal dari Desa Kesiman Kertalangu, Denpasar merupakan bakteri $P$. stewartii subsp. stewartii yang menyebabkan penyakit layu stewart pada tanaman jagung di Denpasar. Penyakit ini baru ditemukan hanya di kota Denpasar dan belum pernah dilaporkan di Provinsi Bali. Penelitian dasar untuk mengetahui karakter molekuler dan biologi $P$. stewartii subsp. stewartii perlu dilakukan sebagai landasan menyusun strategi pengendalian.

\section{UCAPAN TERIMA KASIH}

Penelitian ini dibiayai oleh Direktorat Riset dan Pengabdian Masyarakat, Direktorat Jenderal Penguatan Riset dan Pengembangan, Kementerian Riset, Teknologi, dan Pendidikan Tinggi melalui Penelitian Fundamental dengan Surat Perjanjian Penugasan Pelaksanaan Penelitian No. 486.132/UN14.2/ PNL.01.03.00/2016.

\section{DAFTAR PUSTAKA}

Brady CL, Cleenwerck I, Westhuizen LVD, Venter SN, Coutinho TA, Vos PD. 2012. Pantoea rodasii sp. nov., Pantoea rwandensis sp. nov. and Pantoea wallisii sp. nov., isolated from eucalyptus. Int $\mathrm{J}$ Syst Evol Microbiol. 62:1457-1464. DOI: https://doi.org/10.1099/ijs.0.032615-0. 
Coplin DL, Majerczak DR, Zhang Y, Kim WS, Jock S, Geider K. 2002. Identification of Pantoea stewartii subsp. stewartii by PCR and strain differentiation by PFGE. Plant Dis. 86:304-311. DOI: https://doi. org/10.1094/PDIS.2002.86.3.30.

Dharmayanti NLPI. 2011. Filogenetika molekuler: metode taksonomi organisme berdasarkan sejarah evolusi. Wartazoa. 21(1):15-18.

Freeman ND, Pataky JK. 2001. Levels of Stewart's wilt resistance necessary to prevent reductions in yield of sweet corn hybrids. Plant Dis. 85:12781284. DOI: https://doi.org/10.1094/ PDIS.2001.85.12.1278.

OEPP/EPPO. 2006. Pantoea stewartii Subsp. stewartii. Bulletin OEPP/EPPO. 36: 111115. DOI: https://doi.org/10.1111/j.13652338.2006.00920.x.

[PDSIPKM] Pusat Data dan Sistem Informasi Pertanian Kementerian Pertanian. 2015. Outlook Komodiitas Pertanian Tanaman Pangan. Jagung. PDSIPKM.

Rahma H, Nurbailis, Liswarni Y, Puspita Y. 2010. Uji virulensi beberapa isolat Pantoea stewartii penyebab layu stewart pada bibit jagung (Zea mays L). Manggaro. 11(1):12-17.
Rahma H, Sinaga MS, Surahman M, Giyanto. 2014. First report of Stewart's wilt of maize caused by Pantoea stewartii subsp. stewartii in Bogor district, Indonesia. J. ISSAAS 20(2):131-141.

Stover BC, Muller KF. 2010. TreeGraph 2: combining and visualizing evidence from different phylogenetic analysis. BMC Bioinformatics 11(7):1-9. DOI: https:// doi.org/10.1186/1471-2105-11-7.

Tamura K, Stecher G, Peterson D, Filipski A, Kumar S. 2013. MEGA6: molecular evolutionary genetics analysis version 6.0. Mol Biol Evol. 30(12):2725-2729. DOI: https://doi.org/10.1093/molbev/mst197.

Thompson JD, Gibson TJ, Plewniak F, Jeanmougin F, Higgins DG. 1997. The clustal $\mathrm{X}$ windows interfase: flexible strategies for multiple sequence alignment aided by quality analysis tool. Nucleic Acids Res. 25(24):4876-4882. DOI: https://doi.org/10.1093/nar/25.24.4876.

Wensing A, Zimmermann S, Geider K. 2010. Identification of the corn pathogen Pantoea stewartii by mass spectrometry of wholecell extracts and its detection with novel PCR primers. Appl. Environ. Microbiol. 76(18):6248-6256. DOI: https://doi. org/10.1128/AEM.01032-10. 